\title{
IMPELEMENTATION OF BUSINESS STRATEGY IN THE STATE-OWNED CORPORATION
}

\author{
Ardian Widiarto $^{1)}$, Iqbal Arraniri ${ }^{2)}$, Eldes Willy Filatrovi ${ }^{3)}$ \\ Email: ardian.widiarto@polines.ac.id,iqbal@uniku.ac.id,eldeswillyfilatrovi@stiebankjateng.ac.id \\ ${ }^{1}$ Politeknik Negeri Semarang, Semarang \\ ${ }^{2}$ Universitas Kuningan, Kuningan \\ ${ }^{3}$ Sekolah Tinggi Ilmu Ekonomi, BANK BPD JATENG, Semarang
}

\begin{abstract}
:
Since January 2015 the government has begun to abolish some product subsidies, especially for the marketing area of Java Bali and Madura. This opens up opportunities for new players to enter the oil and gas sector given the increasingly promising profits. The emergence of this new competitor adds to fierce competition between outlets, and to maintain cost efficiency a flexibility strategy and innovation strategy are implemented, especially related to the distribution of products from the company to all outlets where transportation equipment is adjusted so that it can transport various types of products to several outlets at a time. This condition is accompanied by a policy that a conveyance may send to various outlets at a time. Initially, business performance improved rapidly but with the increasing number of outlets there were several product distribution accidents, subsidized deposits, customers switching to other outlets including those owned by foreign companies, and backlog transaction constraints. The problem is that the partner's trust has declined including customers to the company as a result of very strict supervision in the midst of environmental changes as a result of changes in government policies and regulations lately. The sample became the object of research is customer stations in Central Java and Yogyakarta as many as 200 customer in the Gas Station Central Java and Yogyakarta. Methods of data analysis used in this study is a quantitative analysis method where quantitative data analysis method is a method of analysis in the form of figures and calculations using statistical methods. In simplify the analysis process, will be used SEM, AMOS.

Keywords : $\quad$ Product Cohesiveness, Quality Business Strategy, Business Performance, Competitive Advantage
\end{abstract}

\section{Introduction}

The key in maintaining a competitive advantage in today's business world is focused on the consumer. Neither the oil and gas company in Indonesia who need information about who their customers, what is cool customer, how the needs of customers are met as well as other factors. Since January 2015, the government began to remove some product subsidies mainly for the marketing area of Java, Bali and Madura. This opens the opportunity of new entrants in the oil and gas sector given the increasingly promising profit. kemunculaan competitors recently increased competition between outlets increasingly stringent, and to maintain cost efficiencies implemented a strategy of flexibility and innovation strategy, especially regarding the distribution 
of the products of the company to all outlets where transportation customized tank is such that it can carry various types of products to beberapaa outlet once haul, This condition coupled with the policy that the conveyance be sent to various outlets all transports. At first the business performance increased considerably, but with the increasing number of distribution outlets accident occurred some products,

Currently the number of retailers gas station (Fuel Filling Station General) more and more, which was originally only around 400 petrol stations are now multiplied to 800 gas stations in the last five years, ever since January 2015, the government opened the taps as possible to the entry of new players in the field oil distribution through the convenience of the regulation establishing businesses and the elimination of subsidized products in promising areas such as Java, bali and madura (www.liputan6.com/bisnis). This resulted in the narrower profit earned by each retailer pump, the more heavy duty transporter having to serve the delivery of products to various retailers goal of filling stations, in addition to ketatnnya rules applied by the company's impact on the filling stations have become more complex control to avoid deviations on government regulation. The more stringent rules are applied, the more irregularities are found, and conversely the many irregularities, supervision will be tightened. The increasingly strict supervision carried out as a form of distrust towards partners. Among other things the installation of surveillance cameras in some strategic delivery point, such as in Installation / Depot charging. Installation of the system to track the presence of tankers (GPS) ( The increasingly strict supervision carried out as a form of distrust towards partners. Among other things the installation of surveillance cameras in some strategic delivery point, such as in Installation / Depot charging. Installation of the system to track the presence of tankers (GPS) ( The increasingly strict supervision carried out as a form of distrust towards partners. Among other things the installation of surveillance cameras in some strategic delivery point, such as in Installation / Depot charging. Installation of the system to track the presence of tankers (GPS) (www.pertamina.com).

Deviations government regulations are still common among other irregularities subsidies in various cities, among others: Tegal, Semarang, Yogyakarta, Boyolali and Pati. With a total violation of approximately 70 times so that there are shutdowns temporary or permanent outlet, for example in Tegal to be disassembled and does not operate to this day. Closure until the demolition require a large fee from the court when there is up to the cost of dismantling, not to mention if the party concerned does not accept the appeal or the decision on deviation. Accidents occur frequently due to the officer too tired due to memforsir energy to meet employment targets, equipment used easily damaged due to the frequency of work too dense, and often terlupakannya maintenance aspects of both workers and other related assets. This work accident impact on business performance, especially the emergence of cost-reducing corporate earnings and poor public image of the company.

The problems that exist are declining trust partners including customers (customer) against the company as a result of very strict control amid environmental changes as a result of changes in government policies and regulations these days. The problem of research is supported by the research gap in this study showed the differences in the results of previous studies (Matthews and Shulman, 2005; Hong et al., 2012; Wolf and Box, 1987; Harun and Mahmood, 2012). Problems on the formulation of the problem above, to examine the effect of the product cohesiveness area and the quality of the business strategy to improve business performance through competitive advantage. 
Vol-3, Issue-4, 2019 (IJEBAR)

E-ISSN: 2614-1280 P-ISSN 2622-4771

https://jurnal.stie-aas.ac.id/index.php/IJEBAR

\section{Literature Review}

\subsection{Product cohesiveness Area}

Product cohesiveness area a "tug of war between the ability of an individual or organization that is harmonious, and has similarities among members of an area of internal and external such as customers, consumers and governments. Cohesiveness understanding the meaning comes from the cohesion between the smallest particles appeal as similar molecules. Cohesiveness so here is an attraction between members, leading members join in a particular group. So that the product cohesiveness area is an attraction both internal product areas such as inter-product, an external manager or the area between a group of products with external parties such as customers, consumers, governments, and other parties which affects the business existence areas question. The Cohesiveness of Area Products has harmonious attributes that are identified through the closeness of relationships and attractiveness that starts from the location of access, the comfort of the atmosphere of the location, the completeness of the product, to the quality of products (Harun and Mahmood, 2012)

\subsection{Quality Business strategy,}

The formulation of the strategy is the enterprise-level process that includes a variety of activities to formulate the mission and objectives of the company. These activities include: (1) analysis, (2) planning, (3) decision-making, and (4) management, where all of this is based on a system of values and organizational culture (Porter, 2001). Business strategy refers to the primary business strategies are the cornerstone of management. Business strategy reflects: (1) the strategy to be the leader in the marketing, (2) quality, (3) specialty products, which all originated in the factor analysis indicators strategic orientation. Business quality is characterized by: (1) techniques innovative marketing, (2) the placement of skilled labor, and (3) control over distribution channels carefully (Porter, 2001)

\subsection{Competitive Advantage}

Basically every company competing in an industry environment has a desire to be more superior than its competitors. Ferdinand (2000) states that in a competitive market, the company's ability to deliver the performance, especially the financial performance, highly dependent on the degree of competitive advantage. This understanding is related to the company's position compared to what competitors. Companies that continue to pay attention to the development of performance and seeks to improve the performance have the chance of achieving a good competitive position it has an actual company has a strong capital to continue to compete with other companies.

\subsection{Business performance}

According to Ferdinand (2000) is the business performance constructs or factors that are commonly used to measure the impact of a company's strategy. The company's strategy has always aimed to produce a good performance in the form of the performance of the business (such as sales volume, market share or market share and sales growth rates) as well as financial performance. Business performance is formulated as a latent variable (a factor or construct) is the variable that is not measured directly, but is formed through the observed dimensions, in terms of sales volume, customer growth and sales growth (Ferdinand, 2002).

Business performance should be built using multiple dimensions that is not only in sales volume but also the level of subscriber growth as sales volumes will depend on how many customers have been known to the average level of consumption that are fixed (Ferdinand, 2002). Pelham (1997) mentions three indicators of business performance is the effectiveness of the company, sales growth and profit growth relative, in her study also suspect there is a significant relationship between market orientation with the effectiveness of the company and sales growth that will ultimately increase profit growth. 
International Journal of Economics, Business and Accounting Research (IJEBAR)

Peer Reviewed - International Journal

Vol-3, Issue-4, 2019 (IJEBAR)

E-ISSN: 2614-1280 P-ISSN 2622-4771

https://jurnal.stie-aas.ac.id/index.php/IJEBAR

3. Methodology

3.1 Types of Research

This research is quantitative explanatory research based on theories or hypotheses to ntest a phenomenon that occurs (Cooper and Schindler, 2006). Primary data collection techniques use questionnaires directly to respondent.

\subsection{Sample}

The sample became the object of research is customer stations in Central Java and Yogyakarta as many as 200 customer in the Gas Station Central Java and Yogyakarta.

\subsection{Operation Definition}

The operational definition in this study can be explained in Table 3.1 below:

Table 3.1

Operation Definitions and Indicators Research

\begin{tabular}{|c|c|c|c|}
\hline $\begin{array}{l}\text { Variables / } \\
\text { Attributes }\end{array}$ & Operation definition & & Indicator \\
\hline \multirow{4}{*}{$\begin{array}{l}\text { Cohesiveness } \\
\text { product area }\end{array}$} & \multirow{4}{*}{$\begin{array}{l}\text { Cohesiveness Products } \\
\text { Product Area is an attraction } \\
\text { located in one particular } \\
\text { area that is created through a } \\
\text { harmonious relationship and } \\
\text { have appeal to internal and } \\
\text { external }\end{array}$} & X 1.1 & $\begin{array}{l}\text { The closeness of the } \\
\text { relationship between the } \\
\text { product }\end{array}$ \\
\hline & & $\mathrm{X} 1.2$ & $\begin{array}{l}\text { The appeal of the product } \\
\text { quality }\end{array}$ \\
\hline & & X 1.3 & The appeal of entry \\
\hline & & X 1.4 & personal ties \\
\hline \multirow{4}{*}{$\begin{array}{c}\text { Quality Business } \\
\text { Strategy }\end{array}$} & \multirow{4}{*}{$\begin{array}{l}\text { A process is defined as the } \\
\text { level of the company which } \\
\text { includes a variety of } \\
\text { activities to formulate the } \\
\text { mission and objectives of } \\
\text { the company associated with } \\
\text { the marketing process. }\end{array}$} & $\mathrm{X} 2.1$ & $\begin{array}{l}\text { The techniques of } \\
\text { innovative marketing }\end{array}$ \\
\hline & & $\mathrm{X} 2.2$ & $\begin{array}{l}\text { Payment Process Services } \\
\text { (Pay to Busness) }\end{array}$ \\
\hline & & $\mathrm{X} 2.3$ & $\begin{array}{l}\text { Control of distribution } \\
\text { channels carefully }\end{array}$ \\
\hline & & $\mathrm{X} 2.4$ & $\begin{array}{l}\text { The accuracy of net work } \\
\text { planning }\end{array}$ \\
\hline \multirow{3}{*}{$\begin{array}{l}\text { Competitive } \\
\text { Advantage }\end{array}$} & \multirow{3}{*}{$\begin{array}{l}\text { Is defined as a form of a } \\
\text { strategy to help the company } \\
\text { maintain its survival. }\end{array}$} & Y1.1 & Superior in quality \\
\hline & & $\mathrm{Y} 1.2$ & Unggu in accuracy \\
\hline & & $\mathrm{Y} 1.3$ & Superior in speed \\
\hline \multirow{4}{*}{$\begin{array}{c}\text { business } \\
\text { performance }\end{array}$} & \multirow{4}{*}{$\begin{array}{l}\text { Defined as companies that } \\
\text { work effectively. }\end{array}$} & Y2.1 & $\begin{array}{l}\text { Number of Product Sales } \\
\text { in rupiah }\end{array}$ \\
\hline & & Y2.2 & $\begin{array}{l}\text { Diversity Product } \\
\text { Purchases }\end{array}$ \\
\hline & & $\mathrm{Y} 2.3$ & Total quantity of products \\
\hline & & $\mathrm{Y} 2.4$ & $\begin{array}{l}\text { Routines customers buy } \\
\text { products }\end{array}$ \\
\hline
\end{tabular}


Vol-3, Issue-4, 2019 (IJEBAR)

E-ISSN: 2614-1280 P-ISSN 2622-4771

https://jurnal.stie-aas.ac.id/index.php/IJEBAR

\subsection{Reliability and validity test analysis}

Reliability test to test whether the questionnaire is still worthwhile to use. To see eligibility can be seen through Cronbach alpha values, bilakoefisien alpha (a) greater than 0.6 and less than 0.6 if a show is no consistency (Singgih, 2000). Validity test to see whether respondents can understand the questions made, A measuring instrument is said to be valid if the corrected item total correlation greater than or equal to 0.41 (Singgih 2000).

\subsection{Methods and Data Analysis Tools}

\subsubsection{Data analysis method}

Methods of data analysis used in this study is a quantitative analysis method where quantitative data analysis method is a method of analysis in the form of figures and calculations using statistical methods. In simplify the analysis process, will be used SEM, AMOS.

\subsubsection{Data Analysis Tools}

The tools used to process the data in this study is SEM (Structural Equation Model) which is operated by AMOS (Analysis of Moment Structure). In Ferdinand (2014) described, there are seven steps to be taken when using Structural Equation Model (SEM), namely: (1) Development of a model-based theory, (2) Development of flow charts to show causality, (3) Conversion flowcharts in series and structural equation model specification measurement, (4) Selection of input matrix and the estimation technique on a model built, (5) Assess the problem identification, (6) Evaluation criteria Goodness-of-fit, and (7) interpretation and modification of the model.

\section{Result and Discussion}

In this section will explain the descriptive data obtained from respondents. Descriptive data are presented research that can be seen the profile of the research data and the relationships that exist between the variables used in the research (Hair et al, 1995).

\subsection{Respondents by Gender}

Composition of respondents by aspects of sex can be seen in Table 4.1

Table 4.1

Respondents by Gender

\begin{tabular}{c|c|c}
\hline Gender & Frequency & Percentage \\
\hline Female & 98 & 49.00 \\
\hline Male & 112 & 56.00 \\
\hline Total & 200 & 100.0
\end{tabular}

Sources: Primary data are processed, 2018

Table 4.1. showed that male respondents a majority of respondents ie $56.00 \%$ of the total of 200 respondents participated in the study.

\subsection{Testing Assumptions SEM}

\subsubsection{Normality Evaluation Data}

The next test is to see the level of normality of the data used in this study. This test is to examine the value of skewness of the data used, if the value of CR in the data skewness in the range between more or less than 2.58 at the 0.01 level. Results of testing the normality of the data shown in Table 4.2 
International Journal of Economics, Business and Accounting Research (IJEBAR)

Peer Reviewed - International Journal

Vol-3, Issue-4, 2019 (IJEBAR)

E-ISSN: 2614-1280 P-ISSN 2622-4771

https://jurnal.stie-aas.ac.id/index.php/IJEBAR

Table 4.2

Normality Data

\begin{tabular}{l|r|r|r|r|r|r}
\hline variable & Min & Max & skew & cr & kurtosis & cr \\
\hline x12 & 2,000 & 5,000 &,- 312 & -1.273 & -1.129 & -2.305 \\
\hline x13 & 2,000 & 5,000 &,- 206 &,- 840 &,- 943 & -1.924 \\
\hline x14 & 2,000 & 5,000 &,- 097 &,- 395 &,- 987 & -2.014 \\
\hline x15 & 2,000 & 5,000 &,- 392 & -1.600 &,- 869 & -1.773 \\
\hline x9 & 2,000 & 5,000 &,- 227 &,- 926 & -1.205 & -2.460 \\
\hline x10 & 2,000 & 5,000 &,- 844 & -3.446 &,- 004 &,- 007 \\
\hline x11 & 2,000 & 5,000 & -1.157 & -4.721 &, 894 & 1,826 \\
\hline x5 & 1,000 & 5,000 &,- 118 &,- 482 &,- 421 &,- 860 \\
\hline x6 & 1,000 & 5,000 &,- 161 &,- 655 &,- 562 & -1.147 \\
\hline x7 & 1,000 & 5,000 &,- 076 &,- 309 &,- 577 & -1.178 \\
\hline x8 & 1,000 & 5,000 &,- 089 &,- 365 &, 054 &, 110 \\
\hline x4 & 2,000 & 5,000 &,- 062 &,- 254 & -1.025 & -2.092 \\
\hline x3 & 1,000 & 5,000 &, 168 &, 686 &,- 551 & -1.124 \\
\hline x2 & 2,000 & 5,000 &,- 059 &,- 241 &,- 866 & -1.767 \\
\hline x1 & 2,000 & 5,000 &, 349 & 1,423 &,- 356 &,- 727 \\
\hline multivariate & & & & &, 230 &, 051 \\
\hline
\end{tabular}

Source: Research data are processed, 2018

From the data processing are shown in Table 4.2 shows that the there are no CR values for skewness which is outside the range of more or less than 2.58. Thus, the use of research data which meets the requirements of the normality of the data, or it can be said that the research data was normally distributed.

\subsubsection{Multivariate Outliers}

Evaluation of the multivariate outliers need dilakuakan because although the data analyzed showed no outliers on the level of univariate, but the observations that may be outliers when it is combined, Distance Mahalonobis (Mahalonobis Distance) for each observation can be calculated and will show the distance of an observation of the average of all the variables in a multidimensional space (Hair, et al 1995; Norusis, 1994; Tabacnick and Fidel, 1996 in Ferdinand, 2002). To calculate the distance mahalonobis chi-square value based on the degree of smoking by 15 (indicator) at the level of $p<0.001$ was $\pi 2(15,0.001)=37.697$ (based on the distribution table $\pi 2$ ). From the results of data processing can be seen that the maximum distance mahalainobis 35.299. So in this analysis did not reveal any outliers.

Table 4.3

multivariate Outliers

\begin{tabular}{r|r|r|r}
\hline Observation number & D-squared Mahalanobis & p1 & p2 \\
\hline 7 & 34.339 &, 003 &, 263 \\
\hline 30 & 29.539 & .014 &, 398 \\
\hline 99 & 27.231 &, 027 &, 506
\end{tabular}


International Journal of Economics, Business and Accounting Research (IJEBAR)

Peer Reviewed - International Journal

Vol-3, Issue-4, 2019 (IJEBAR)

E-ISSN: 2614-1280 P-ISSN 2622-4771

https://jurnal.stie-aas.ac.id/index.php/IJEBAR

\begin{tabular}{r|r|r|r}
\hline---- & --- & --- & --- \\
\hline---- & --- & --- & --- \\
\hline 10 & 6.871 &, 961 &, 249 \\
\hline 87 & 6.540 &, 969 &, 183 \\
\hline 5 & 5.851 &, 982 &, 165
\end{tabular}

Source: Research data are processed, 2018

\subsection{Analysis of Structural Equation Modeling}

Subsequent analysis is the analysis of Structural Equation Model (SEM) as a full model, after analysis of the level of the indicators unidimensionalitas forming latent variables tested by confirmatory factor analysis. Analysis of the data processing at the stage of full model SEM carried out to test the suitability and statistical tests. The results of data processing for the full model SEM analysis shown in Figure 4.1 and Table 4.4

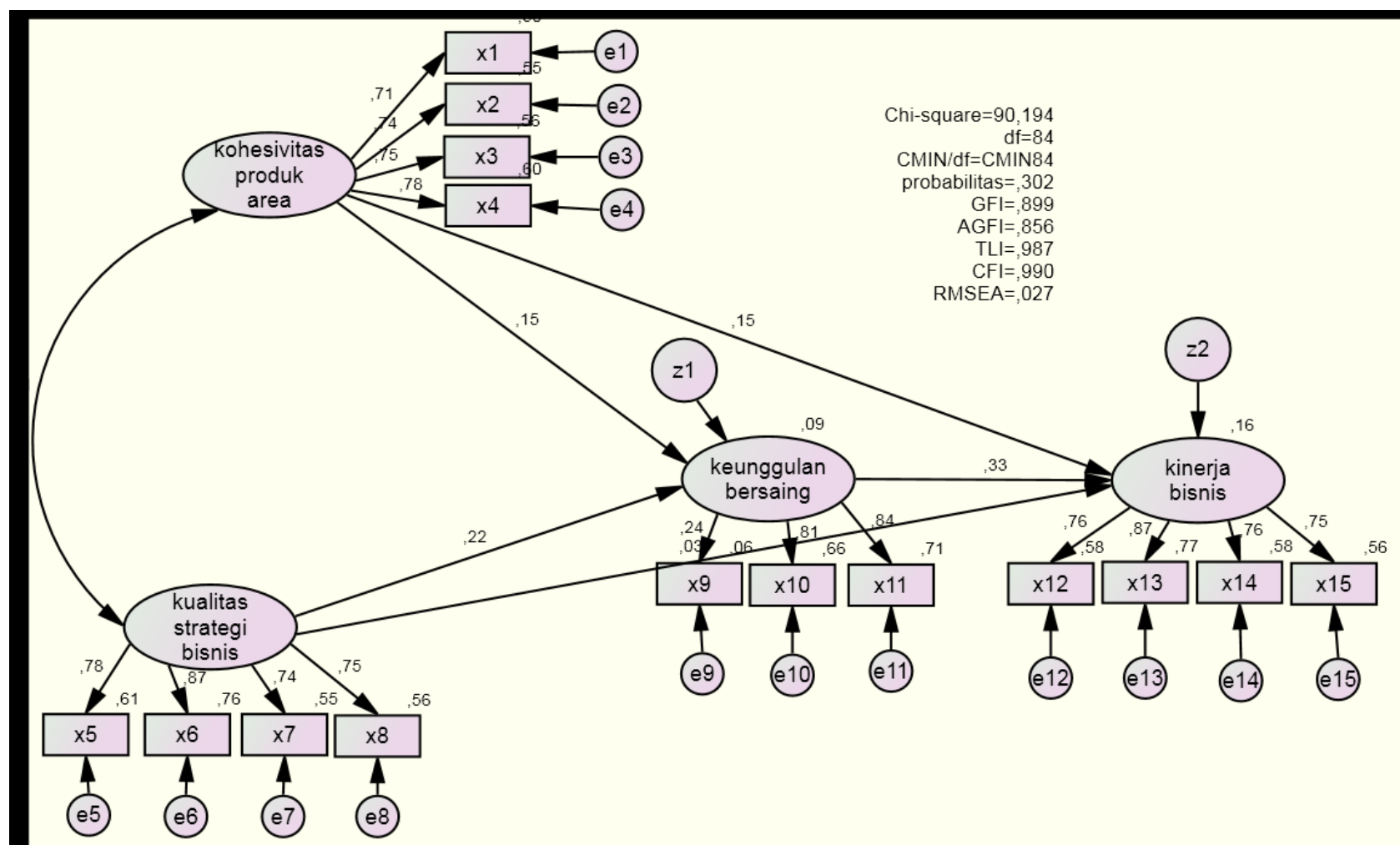




\section{Table 4.4}

Feasibility Model Testing Results

SEM analysis

\begin{tabular}{l|c|c|c}
\hline $\begin{array}{c}\text { Goodness of Fit } \\
\text { Index }\end{array}$ & Cut-off Value & Results Analysis & $\begin{array}{c}\text { evaluation } \\
\text { Model }\end{array}$ \\
\hline Chi - Square & $<106.394 \mathrm{df} 84$ & 90.194 & Well \\
\hline probability & $\geq 0: 05$ & 0,302 & Well \\
\hline RMSEA & $\leq 0: 08$ & 0,027 & Well \\
\hline GFI & $\geq 0.90$ & 0.899 & marginal \\
\hline AGFI & $\geq 0.90$ & 0.856 & marginal \\
\hline CMIN / df & $\leq 2.00$ & 1.074 & Well \\
TLI & $\geq 0.95$ & .987 & Well \\
\hline CFI & $\geq 0.95$ & 0,990 & Well
\end{tabular}

Source: Research data are processed, 2018

For a statistical test to the relationship between variables that will be used as a basis for answering the research hypotheses have been proposed. Statistical test results with SEM processing done by looking at a significance level of relationships between variables revealed through the value of probability (p) and and Critical Ratio (CR) of each relationship between variables. For statistical testing process is revealed in Table 4.5

Table 4.5

Standardized Regression Weight

\begin{tabular}{l|l|l|r|r|r|r|l}
\hline \multicolumn{2}{l}{ Variable } & estimate & SE & CR & P & Information \\
\hline keunggulan_bersaing & $<---$ & kohesivitas_produk_area &, 147 &, 122 & 2,202 &, 029 & Sig \\
\hline keunggulan_bersaing & $<---$ & kualitas_strategi_bisnis &, 192 &, 110 & 2,751 &, 003 & Sig \\
\hline kinerja_bisnis & $<---$ & kohesivitas_produk_area &, 175 &, 140 & 2,248 &, 012 & Sig \\
\hline kinerja_bisnis & $<---$ & kualitas_strategi_bisnis &, 027 &, 125 & 214 &, 830 & No Sig \\
\hline kinerja_bisnis & $<---$ & keunggulan_bersaing &, 389 &, 149 & 2,608 &, 009 & Sig
\end{tabular}

Source: Research data are processed, 2018

\subsection{Hypothesis Result}

The hypothesis of this study five hypotheses. The conclusions of the five hypotheses are as follows:

1. The test results the effect product cohesiveness area to competitive advantage can be inferred cohesiveness on the product areas of competitive advantage.

2. The test results the effect quality of the business strategy to competitive advantage can be inferred quality of business strategy on the competitive advantage.

3. Results of testing the effect product cohesiveness influence on the performance of the business area concluded cohesiveness area product on the performance of the business.

4. The test results influence the quality of the business strategy to business performance can be summed quality business strategy does not affect the performance of the business

5. Results of testing the effect of competitive advantages to business performance can be inferred a competitive advantage on the performance of the business. 


\section{Conclusion}

Gas Station Management PT Pertamina (Persero) Central Java and Yogyakarta should further enhance the competitive advantage that existing staff at the gas station competitive with other gas stations and Gas Station Management PT Pertamina (Persero) Central Java and Yogyakarta have to pay attention to the performance of the business conducted at the gas station employee par each. The results of this research and the limitations found in the study can be used as a source of ideas for the development of this research in the future, the research suggested extension of this study is to increase endogenous variables that affect business performance.

\section{References}

Aloulou, W. (2000), "Entrepreneurial Orientation Diagnosis in SMEs : Some Conceptual dan Methodological Dimensions", Entrepreneurship Research in Europe: Specificities dan erspective, University of Sfacx, Tunisia, pp. 1-27.

Ferdinand, Augusty Tae, (2000), "Manajemen Pemasaran Sebuah Pendekatan Strategik", Research Paper Series, No, 01, Maret, pp. 1-55 Ferdinand, Augusty Tae, 2002, "Kualitas Strategi Pemasaran : Sebuah Studi Pendahuluan", Jurnal Sains Pemasaran Indonesia, Vol. 1, No. 01, Mei, pp.107-119

Ferdinand, Augusty (2002), Structural Equation Modelling Dalam Penelitian Manajemen, Badan Penerbit Universitas Diponegoro, Semarang Ferdinand, Augusty (2002), Structural Equation Modelling Dalam Penelitian Manajemen, Badan Penerbit Universitas Diponegoro, Semarang

Harun, Mohd Zainal Munshid Bin dan Rosli Bin Mahmood, (2012), "The Relationship between Group Cohesiveness and Performance: An Empirical Study of Cooperatives Movement in Malaysia," International Journal of Cooperative Studies

Hong, Paul; Yong Won Park; dan Suk Bong Choi, (2012), "Achieving knowledge management excellent for competitive advantage: research model for small and medium enterprises," University of Toledo

Kickul, Jill dan Lisa K Gundry, (2002), "Prospecting for strategic advantage: the proactive entrepreneurial personality and small firm innovation," Jounal of Small Bussiness Management 105

Matthews, Judy dan Arthur Shulman, (2005), "Competitive advantage in public sector organization: explaining the public good/sustainable competitive advantage paradox," Journal of Bussiness Research

Papulova, Emilia dan Zuzana Papulova, (2006), "Competitive strategy and competitive advantages of small and midsize manufacturing enterprises in Slovakia," E Leader, Slovakia

Pelham, Alfred M(1997), "Mediating Influencess on The Relationship Between Market Orientation and Profitability in Small Industrial Firms," Journal of Marketing Theory and Practice, Summer, 1997, pp.55-67 
International Journal of Economics, Business and Accounting Research (IJEBAR)

Peer Reviewed - International Journal

Vol-3, Issue-4, 2019 (IJEBAR)

E-ISSN: 2614-1280 P-ISSN 2622-4771

https://jurnal.stie-aas.ac.id/index.php/IJEBAR

Porter, Michael E, (2001). Keunggulan bersaing, PT. Gramedia Jakarta

Porter, Michael E dan Mark R Kramer, (2002), "The competitive advantage of corporate philanthropy," Harvard Bussiness Review

Robbins, Stephen P, 1996, Organizational Behaviour Concept, Controversiest, Applications, Prentice Hall. Inc, Englewoods Cliffs

Shin; Soo-Young dan Won-Woo Park, (2015), "Moderating Effects of Group Cohesiveness in CompetencyPerformance Relationships: A Multi-Level Study," Journal of Behavioral Studies in Business

Singgih, Santoso, (2000), SPSS ( Statistical Product and Service Solutions). Penerbit PT. Elex Media Komputindo-Kelompok Gramedia .Jakarta.

Werner, Reinartz; Kraft, Manfred; Hoyer, Wayne, D, (2004), The Customer Relatiuonship Manajement Process: Its Measurement and Impact on Performance, Journal of Marketing Research, Vol.41, Iss: 3, pp. 181-199

Wolf Thomas M. Box, (1987), "TEAM COHESION EFFECTS ON BUSINESS GAME PERFORMANCE," Developments in Business Simulation \& Experiential Exercises, Volume 14, 1987 